\title{
Student Cheating Habits: A Predictor Of Workplace Deviance
}

\author{
Sharron M. Graves, (Email: sgraves@sfasu.edu), Stephen F. Austin State University
}

\begin{abstract}
Unethical behavior seems to be increasing exponentially in every facet of today's business environment. Property and production deviance are just two of the unethical behaviors exhibited by employees. According to a study conducted by S. Nonis and C. Swift (2001), students who engage in dishonest acts in college classes are more likely to engage in dishonest acts in the workplace. Research conducted during the three year period 2002 - 2005 by Don McCabe in conjunction with The Center for Academic Integrity at Duke University reveals that 70 percent of the 50,000 undergraduate students surveyed admit to some cheating (McCabe 2005). This article reports the results of a student survey documenting the self-reported cheating habits of business and non-business majors and their reported involvement in deviant activities in the workplace. The research indicates that a higher percentage of non-business majors report cheating on tests and homework than business majors and students who cheat in high school and/or college are more likely to engage in certain deviant behaviors in the workplace. In addition, the article also compares the percentage of students engaging in property and production deviance with the results of an earlier study by $R$. C. Hollinger and J. P. Clark examining workplace deviance among employees in the retail sector.
\end{abstract}

\section{INTRODUCTION}

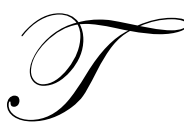

oday's college students are growing up in a society where ethical values are declining and scandals involving dishonesty in government, business and other organizations are frequent occurrences. Many research and media reports have addressed the pervasiveness of academic dishonesty. In 1964, Bill Bowers surveyed more than 5,000 college students and found that 75 percent reported engaging in one or more incidents of academic dishonesty. His study was repeated in 1994 by McCabe and Trevino (1997) and only a modest increase in academic dishonesty was reported. The study, however, did report a significant increase in cheating on exams and cheating by women. In a 2002 report for CNN, Kathy Slobogin reported on a national survey of 4,500 high school students conducted by Rutgers' Management Research Education Center. The report revealed that 75 percent of the students admitted being engaged in serious cheating (Slobogin 2002). Similar research conducted by Don McCabe for The Center for Academic Integrity at Duke University revealed that 70 percent of the 50,000 undergraduate students surveyed during 2002 to 2005 , on some 60 campuses nationwide, reported cheating (McCabe 2005).

Research has been conducted on the relationship between academic dishonesty and unethical business practices. Sims (1993) investigated whether the range and severity of academic dishonesty engaged in during undergraduate studies related to the range and severity of dishonesty engaged in later during employment. His study of $60 \mathrm{MBA}$ students indicated that students who admitted to acts of academic dishonesty also admitted to a wide range of work related dishonesty. In addition, students who reported being engaged in behaviors considered severely dishonest in college were also engaged in behaviors considered severely dishonest in the work place.

From well-known documented research it is evident that cheating has increased at least three fold over the last 65 years. As alarming as this is, the numbers have more or less stabilized over the past 25 years at 70 to $75 \%$. Table 1 reports representative survey results of prior research covering seven decades. There are many surveys relating to academic dishonesty; the ones listed are consistent with results reported by other researchers. 
Table 1

Survey Results from Prior Research on Student Cheating

\begin{tabular}{||c|c|c||}
\hline & The Center for Academic Integrity, & $70 \%$ \\
\hline 2005 & Duke University & $75 \%$ \\
\hline 2002 & Rutgers' Management Education Center & $91 \%$ \\
\hline 1990 & Miami University & $75 \%$ \\
\hline 1980 & J. S. Baird & $55 \%$ \\
\hline 1970 & Stannard \& Bowers & $49 \%$ \\
\hline 1960 & R. K. Goldsen & $38 \%$ \\
\hline 1941 & R. K. Goldsen & $23 \%$ \\
\hline
\end{tabular}

Source: Sims 1993, CNN 2002 and McCabe 2005.

In 1983, Hollinger and Clark (H \& C) (1983) published federally-funded research involving surveys of nearly 10,000 American workers in the retail, hospital and manufacturing sectors. They employed a variety of research methods including a questionnaire survey of employees, interviews with organizational executives, and face-to-face employee interviews. One part of their questionnaire survey asked respondents to indicate the extent of their involvement in various forms of deviant behavior in the workplace. They divided the list of deviant activities into property-deviant and production-deviant actions. Property deviance dealt with the theft of property belonging to the company, fellow workers or outsiders while production deviance included counterproductive behavior regarding the use of time and the amount or quality of work produced by the employee (Hollinger and Clark 1983).

Although the results varied by sector, the percentage of employees who engaged in production-deviant activities was higher in all three sectors than those engaged in property deviant activities. For example, 35.1 percent of the retail employees engaged in property-deviant activities while 65.4 percent engaged in production-deviant activities. Employees working in the manufacturing sector reported a much higher percentage of participation in production-deviant behavior (82.2) than either the retail sector (65.4) or the hospital sector (62.9). Their participation in property-deviant activities only varied slightly from the other sectors (Hollinger and Clark 1983).

According to Hollinger and Lanza-Kaduce (1996), there are two popular research strategies used to analyze academic dishonesty. One involves contriving situations that provide students with an opportunity to cheat and the other uses self-reported student responses to an anonymous or confidential survey. Even though the results from both methods vary greatly and the potential drawback of under reporting exists, Scheers and Dayton (1987) believe that the best way to obtain detailed information on the cheating habits of students is the use of self-administered surveys.

Given the fact that academic dishonesty has increased over the past seven decades, the author questions whether today's business and non-business students have the same propensity toward workplace-deviant behavior as employees included in the Hollinger and Clark Survey. This study addresses the level of cheating among business and non-business students in both high school and college and documents their self-reported involvement in property- and production-deviant activities.

\section{METHODOLOGY}

A questionnaire survey was developed by the author that included the deviant activities identified by Hollinger and Clark and included in their retail-sector survey. The retail survey was chosen because more students have retail work experience than hospital or manufacturing experience. Additional items were added to reflect today's work environment; e. g. surfing the Web and playing computer games on company time. The questionnaire also included questions regarding cheating on tests and/or homework in high school and college. 
Responses were collected from students in undergraduate and graduate business courses which included business and non-business majors at a public, AACSB accredited university in Texas. Questionnaires were administered in class and students were assured their individual responses would be kept anonymous. Classes were selected to obtain a representation of junior, senior and graduate student responses. To ensure a student's response was not double counted, students taking multiple surveyed courses were instructed to fill out only one questionnaire. After eliminating incomplete questionnaires, 124 useable questionnaires were obtained. The two-part questionnaire included sections on cheating habits and deviant activities. When asked about their participation in deviant activities, students were instructed to indicate whether or not they had ever engaged in the activities listed. If a student had not had the opportunity to engage in a particular activity, he was instructed to respond accordingly.

\section{STUDENT CHEATING SURVEY RESULTS}

Table 2 reports the results of the study and indicates the percent of students who admitted cheating on tests and or homework in high school and college. Business students are reported by academic major and all nonbusiness majors are grouped in the "other" category. One can see from the percentages that an equal or higher percentage of students report cheating on homework than on tests in high school, and except for management majors the same is true for college. Although the percentage of students who cheat in college is much smaller, in the final analysis students who cheat on tests and/or homework in high school engage in a higher percentage of deviant activities in the workplace. When the responses of all business majors are combined, they report cheating less in all categories than non-business majors except for cheating on college tests where the percentages are almost identical. Accounting and marketing majors cheat less on college tests and homework than other majors included in the study and the average of all business majors.

Table 2

Cheating on Tests and Homework (Percentages)

\begin{tabular}{||c|c|c|c|c||}
\hline Major & $\begin{array}{c}\text { HS } \\
\text { Tests }\end{array}$ & $\begin{array}{c}\text { HS } \\
\text { HW }\end{array}$ & $\begin{array}{c}\text { College } \\
\text { Tests }\end{array}$ & $\begin{array}{c}\text { College } \\
\text { HW }\end{array}$ \\
\hline Accounting & 64 & 76 & 16 & 24 \\
\hline Finance & $60^{*}$ & $60^{*}$ & $40^{*}$ & $60^{*}$ \\
\hline General Business & 48 & 66 & 21 & 45 \\
\hline Management & 55 & 55 & 17 & 64 \\
\hline Marketing & 67 & 75 & 21 & 25 \\
\hline Other & 64 & 90 & 22 & 51 \\
\hline All Business Majors & 57 & 68 & 39 & 39 \\
\hline
\end{tabular}

*This percentage reflects the responses of only five finance majors and are not included in the remainder of the paper.

\section{INVOLVEMENT IN PROPERTY AND PRODUCTION DEVIANCE}

Property deviance includes theft of assets belonging to the company, fellow workers or outsiders while production deviance deals with counterproductive behavior regarding the use of time and the amount or quality of work produced by the employee (Hollinger and Clark 1983). A comparison of the student responses to the responses of the employees in the $\mathrm{H} \& \mathrm{C}$ retail survey reveals that students have a higher propensity toward both property- and production-deviant activities. Tables 3 and 4 compare the responses from the Hollinger and Clark survey with those of the student survey. 
Table 3

Property Deviance Comparison (Percentages)

\begin{tabular}{|c|c|c|c|c|c|c|}
\hline Involvement & Hollinger & ACCT & GBUS & MGMT & MKTG & OTHER \\
\hline Abuse employee discount privilege & 29 & 44 & 26 & 33 & 45 & 35 \\
\hline Steal store merchandise & 7 & $\mathbf{1 4}$ & $\mathbf{2 6}$ & $\mathbf{2 0}$ & 0 & $\mathbf{2 3}$ \\
\hline Overstate hours worked & 6 & $\mathbf{3 2}$ & $\mathbf{1 5}$ & $\mathbf{2 7}$ & $\mathbf{3 3}$ & $\mathbf{3 4}$ \\
\hline Purposely underring merchandise & 3 & $\mathbf{1 7}$ & $\mathbf{2 4}$ & $\mathbf{3 3}$ & $\mathbf{3 8}$ & $\mathbf{2 0}$ \\
\hline Overstate expenses for reimbursement & 2 & $\mathbf{1 3}$ & $\mathbf{2 1}$ & $\mathbf{2 5}$ & $\mathbf{2 9}$ & $\mathbf{7}$ \\
\hline Steal company tools or equipment & 9 & 5 & 7 & 9 & 10 & 6 \\
\hline
\end{tabular}

The results are very discouraging; however, the numbers in Table 3 are much more favorable than the ones in Table 4 reporting production-deviant activities. The figures in bold in Table 3 show that 2 to 13 times more students engage in property-deviant activities than respondents in the Hollinger and Clark survey. The percentage of students stealing tools or equipment from their employers is basically the same as in the earlier survey. Participants in both surveys must consider abusing the employee discount privilege a relatively minor transgression because a higher percentage of all participants report engaging in that activity than in other deviant activities. There is not a material difference between the involvement of business majors and non-business majors in the property-deviance areas.

The first three activities listed in Table 4 are pertinent to today's work environment but were not in 1983; therefore, they were not included in the $\mathrm{H} \& \mathrm{C}$ study. The responses to these activities certainly indicate that employers need to be more diligent in monitoring such activities. If company profit margins are shrinking, a high level of involvement in production-deviant activities is extremely detrimental to a company's bottom line. According to a 2002 survey conducted by Websense and Harris Interactive and published in the September 30, 2002, issue of Newsweek, only six percent of employees never surf the Web on company time. Forty-seven percent of the employees report visiting Web sites from one to four hours a week and another ten percent report five to nine hours a week. Fifty-six percent of the employees report they would rather give up coffee than give up surfing the Web.

Seventy-seven percent of the non-business majors report surfing the Web during working hours which is 13 percentage points higher than the highest percentage reported by business majors. Fifty percent or more of management majors engage in all of the activities listed except for working under the influence of alcohol and drugs. One must be concerned with this statistic because it reflects the work ethic of future business managers. Employees usually tend to mimic the behavior of the company's management, and these soon to be managers will not be a good influence on their peers or subordinates. In addition, they, most likely, will not expect a very high level of performance from their employees. Approximately 25 percent of students report working under the influence of drugs or alcohol which is more than triple the employee responses to the $\mathrm{H} \& \mathrm{C}$ survey. Management and nonbusiness majors report the highest percentage (27\%), and accounting majors fared the best, reporting only 13 percent. The only area in which students in any major report a lower percentage of involvement than the employees in the $\mathrm{H} \& \mathrm{C}$ survey is taking long lunch breaks without approval. Student responses in all other activities are approximately two to six times higher than those in the earlier survey.

Although the results vary by sector in the $\mathrm{H} \& \mathrm{C}$ survey, the percentage of employees who engage in production deviance is higher in all three sectors than those engaging in property deviance. The same is true of the student survey. From 13 to 100 percent of students engage in production deviance, an average of 59 percent, while only 5 to 45 percent, an average of 20.8 percent, engage in property deviance. 
Table 4

Production Deviance Comparison (Percentages)

\begin{tabular}{|c|c|c|c|c|c|c|}
\hline Involvement & Hollinger & ACC & GBU & MGM & MKT & Other \\
\hline $\begin{array}{c}\text { Surf the web for personal use during } \\
\text { working hours }\end{array}$ & & 36 & 58 & 60 & 64 & 77 \\
\hline Play computer games on company time. & & 60 & 30 & 60 & 36 & 56 \\
\hline $\begin{array}{c}\text { Use an employer's long distance phone } \\
\text { line for personal use }\end{array}$ & & 26 & 8 & 50 & 25 & 24 \\
\hline Call in sick to keep from going to work & 17.1 & 80 & 71 & 100 & 92 & 79 \\
\hline Take a long lunch break without approval & 56.0 & 60 & 41 & 55 & 71 & 46 \\
\hline Do slow and/or sloppy work & 15.7 & 54 & 87 & 55 & 71 & 50 \\
\hline $\begin{array}{c}\text { Work under the influence of alcohol or } \\
\text { drugs }\end{array}$ & 7.5 & 13 & 24 & 27 & 25 & 27 \\
\hline Go to work late and leave early & 32.3 & 88 & 86 & 100 & 92 & 79 \\
\hline
\end{tabular}

\section{CHEATING HABITS AND PROPERTY AND PRODUCTION DEVIANCE}

There are numerous articles that address cheating and other forms of academic and workplace dishonesty or deviance. However, there is very little research that links the two behaviors. In a 1993 study of 60 MBA students, it was found "that subjects who admitted to having engaged in a wide range of academic dishonesty also admitted to a wide range of work-related dishonesty" (Sims 1993). An article by Nonis and Swift (2001) reports the results of a study of 1,051 students on six different college campuses. The results of their study indicate that "students who engage in dishonest acts in college classes were more likely to engage in dishonest acts in the workplace" (Nonis and Swift 2001). Another study by K. Blankenship and B. Whitley revealed that "cheaters scored higher than noncheaters on measures of unreliability and risky driving behaviors" (Blankenship and Whitley 2000).

In this part of the study, all student responses to 21 deviant workplace activities are analyzed to determine whether students engaging in various behaviors also report cheating on tests or homework in high school and/or college. The responses vary widely; therefore, the activities with low involvement are not reflected in the following graphs.

The survey results indicate that students who do not cheat on tests or homework are not heavily involved in the deviant activities listed in Figure 1. Although a lower percentage of students who engage in the activities report cheating in college, the real indicator is their history of high school cheating habits. The percentages reflect a combination of students who report cheating on tests and homework. Between 82 and 93 percent of the students who abuse the employee discount privilege, overstate the number of hours worked, steal store merchandise and use the employer's long distant line for personal use report cheating in high school. The college cheating percentage ranges from 52 to 71 percent.

Figure 2 indicates that non cheaters are slightly more active in the production-deviance area. While the percentage of students cheating in high school remains relative constant, the percent of college cheaters drops about ten percentage points. One must wonder what factors contribute to the decrease. Do students cheat less in college because they are more mature, cheating becomes less acceptable, cheating becomes more difficult or for some other reason? This is a good topic for future study. 
Figure 1

Relationship between Cheating and Property-Deviant Activities

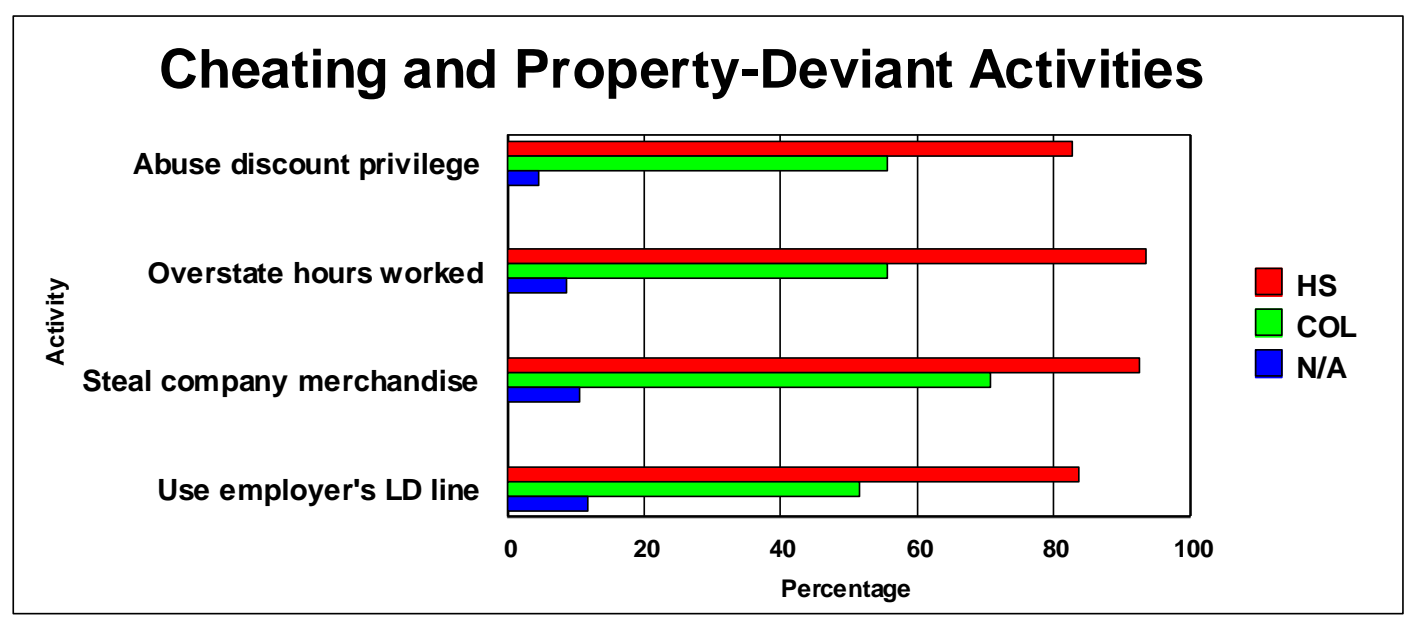

Figure 2

Relationship between Cheating and Production Deviant Activities

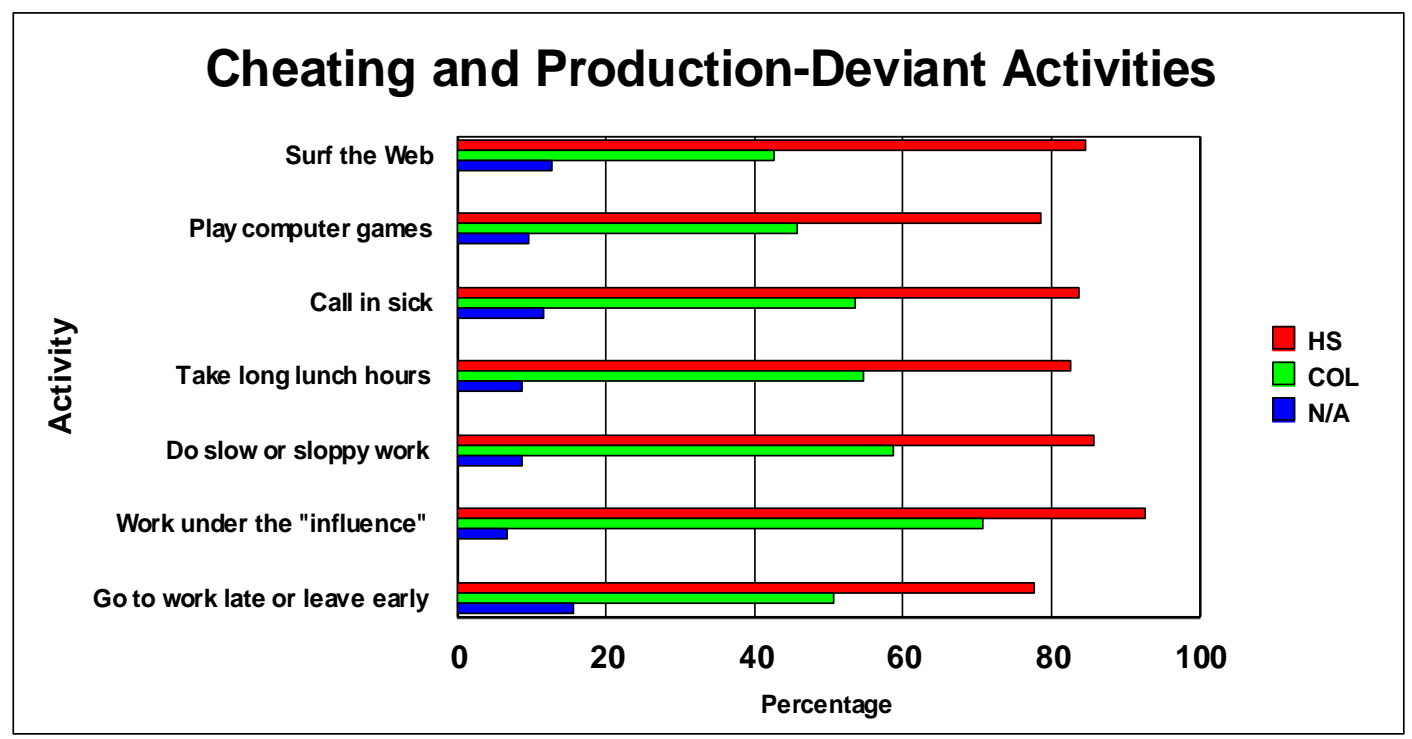

The current generation of high school students shows little sense of ethical indignation about cheating, and many believe the pressure to do well makes cheating almost a necessity. According to a 2002 CNN report, 75 percent of high school students engage in serious cheating, and 50 percent of those do not even think copying answers from a test qualifies as cheating. The most common reason for cheating cited by high school students in Don McCabe's research is the poor example set by the adult world. Students don't understand why they should be held to a higher standard than their adult "role models" (McGabe 2005). When these students enroll in the nation's colleges and universities, they already have the attitude that cheating is an acceptable form of behavior.

There are some positive steps educators can take to discourage cheating on tests. According to Hollinger and Lanza-Kaduce, students report the number one counter measure is test question scrambling. About two-third of the students in their survey believe that small class size, multiple test proctors, unique makeup exams, and multiple 
alternate tests are also effective measures. In addition, measures to reduce test anxiety, i. e. exam study sheets and giving students access to old exams, will eliminate the pressure to cheat (Hollinger and Lanza-Kaduce 1996). The problem with these tactics is that they do not change the moral mindset of the students; they only make cheating more difficult or help to eliminate the need to cheat.

Adding to the problem that students condone cheating as being acceptable is the fact that faculty members are reluctant to take action against suspected cheaters. According to the Center for Academic Integrity, assessment surveys of some 10,000 faculty members reveal that $44 \%$ acknowledge that students cheat in their courses, and they never report them to campus administrators (McCabe 2005). This lack of responsibility on the part of educators sends the message that cheating is an acceptable behavior.

The high correlation between cheating and workplace deviance has tremendous implications for both employers and academicians. Students who cultivate a cheating mentality in the academic arena will more than likely demonstrate the same behavior in the workplace. Educators at all academic levels must take the responsibility for encouraging ethical behavior among students. They need to openly state that cheating is unacceptable and that violators will be punished. Since students' values and their concepts of what constitutes cheating may differ, it is helpful for academic institution have a written policy that outlines acceptable behavior and the consequences for unacceptable behavior.

According to McCabe, academic honor codes are an effective means of reducing cheating. He reports that "serious test cheating on campuses with honor codes is typically $1 / 3$ to $1 / 2$ lower than the level on campuses that do not have honor codes" (McCabe 2005).

Traditional honor codes normally have some provision for unproctored exams, require students to sign pledges attesting to the integrity of their work, allow students to have a primary role in the judicial process and encourage or require students to report cheating among their peers. In contrast, modified honor codes usually allow students to have a strong say in the judicial process, but they do not require unproctored exams, pledges and ratting on their peers. McCabe's research shows that even modified honor codes are successful because they have a campus-wide focus on academic integrity.

\section{CONCLUSION}

This study's findings are similar to those of other studies focusing on the relationship between cheating and unethical behavior in the workplace. Students who cheat on tests and/or homework in high school and/or college are more likely to engage in property- and production-deviant activities than their counterparts who do not cheat. However, this study indicates that high school cheating habits are a better indicator of a person's deviant behavior in the workplace. Educators at all levels must take the responsibility for changing the mindset of students from believing that cheating is acceptable to believing that it will not be tolerated. Research indicates that the best alternative is for educational institutions to implement and strictly enforce an honor code. Even modified honor codes prove to be a successful deterrent.

Compared to the Hollinger and Clark survey of retail employees today's students are as much as 13 times more likely to engage in certain deviant behavior. Perhaps employers should consider pre-employment screening which includes a test of applicants' academic cheating habits. If employers can avoid hiring individuals with a history of academic cheating, they can reduce the cost associated with deviant employee behavior. Employers should also take an active interest in curbing academic dishonesty (cheating) by working with students, faculty members and administrators to encourage ethical student behavior.

\section{REFERENCES}

1. Blankenship, K. and Whitley, B. 2000. Relation of general deviance to academic dishonesty. Ethic \& Behavior 10(1): 1-12.

2. Brown, B. S. and Emmett, D. 2001. Explaining variations in the level of academic dishonesty in studies of college students: Some new evidence. College Student Journal 35(4): 529-38. 
3. Hollinger, R. C. and Clark, J. P. 1983. Theft by employees. Lexington, MA: Lexington Books.

4. Hollinger, R. C. and Lanza-Kaduce, L. 1996. Academic dishonesty and the perceived effectiveness of counter- measures: An empirical survey of cheating at a major public university. NASPA Journal 33: 292306.

5. McCabe, D. 2005. Levels of cheating and plagiarism remain high, The Center for Academic Integrity, http://www.academicintegrity.org/cai_research.asp (accessed August 19, 2006).

6. McCabe, D. L., \& Trevino, L. K. 1997. Individual and contextual influences on academic dishonesty: A multicampus investigation. Research in Higher Education 38: 379-96.

7. Nonis, S., \& Swift, C. O. 2001. An examination of the relationship between academic dishonesty and workplace dishonesty: A multicampus investigation. The Journal of Education for Business 76(6): 69-77.

8. Sims, R. L. 1993. The relationship between academic dishonesty and unethical business practices. Journal of Education for Business 68(4): 207-13.

9. $\quad$ Slobogin, K. 2002. Survey: Many students say cheating's OK. CNN.com, April 5, 2002.

10. Synfax Weekly Reporter. New research on academic integrity: The success of modified honor codes. Synfax Weekly Report May 15, 2000: 975, http://www.collegepubs.com/fer/SFX000515.shtml (accessed August 19, 2006).

\section{NOTES}

